\title{
PREVALENCE OF TUBERCULOSIS IN SOUTH-WEST ROMANIA AND THE DIRECT COSTS BURDEN
}

\author{
ANDREEA-DANIELA MECA ${ }^{1 \#,}$, MIHAELA-SIMONA SUBTIRELU ${ }^{2 \#}$, ADINA TURCU- \\ STIOLICA $^{2 *}$, FLOAREA MIMI NIȚU ${ }^{3 \#}$, MARIA BOGDAN ${ }^{1}$, MARIUS MATEI ${ }^{4}$, RAMONA \\ CIOBOATĂ ${ }^{3}$, BOGDAN PETRE STĂNOIU ${ }^{5}$, CĂTĂLINA-GABRIELA PISOSCHI ${ }^{6}$
}

\author{
${ }^{I}$ Department of Pharmacology, University of Medicine and Pharmacy, Craiova, Romania \\ ${ }^{2}$ Department of Pharmacoeconomics, University of Medicine and Pharmacy, Craiova, Romania \\ ${ }^{3}$ Department of Pneumology, University of Medicine and Pharmacy, Craiova, Romania \\ ${ }^{4}$ Department of Histology, University of Medicine and Pharmacy of Craiova, Romania \\ ${ }^{5}$ Department of Cell Biology, University of Medicine and Pharmacy, Craiova, Romania \\ ${ }^{6}$ Department of Biochemistry, University of Medicine and Pharmacy, Craiova, Romania
}

*corresponding author: adina.turcu@gmail.com

${ }^{\#}$ Authors with equal contribution.

\begin{abstract}
Antituberculotic treatment has the purpose to rapidly stop transmission and to prevent relapse, in order to further reduce the tuberculosis (TB) burden and development of resistant bacterial strains. Romania had the highest TB incidence among EU countries and since 2018, an active TB screening program has been introduced among vulnerable populations. The aim of this study was to identify all the patients diagnosed with TB in Dolj County, Romania, in 2018 and to evaluate their characteristics, as well as to estimate the amounts reimbursed by the National Health Insurance Fund, based on the data reported by the hospitals from Dolj, Romania. The treatment was analysed through descriptive statistics for hospitalized cases based on a principal diagnosis of TB which received continuous care in 2018. In Dolj County, 6378 people, with a mean age of $39 \pm 30.42$ years, were infected with Mycobacterium tuberculosis in 2018. More than a half were males $(3,723-58 \%)$ and $2,655-42 \%$ were females. The prevalence of TB in Dolj County in 2018 was $1.01 \%$. The treatment outcomes of TB patients were: $1,441(22.6 \%)$ cured, 5,036 (78.9\%) treatment completed, $25(0.4 \%)$ died, $47(0.7 \%)$ failed and $163(2.6 \%)$ interrupted. The number of those with treatment failed and treatment interrupted represents an unfavourable treatment outcome and it was less than 210 patients $(3.3 \%$ ) in 2018 , which is a very good indicator compared with the $85 \%$ World Health Organization (WHO) target of TB treatment success. In order to evaluate TB control strategies, it is essential to trace TB incidence, prevalence and mortality, but also to comprehend treatment outcomes.
\end{abstract}

\section{Rezumat}

Tratamentul antituberculos are scopul de a opri rapid transmiterea bacteriană şi de a preveni recidiva, astfel încât povara tuberculozei (TB) să fie diminuată, iar dezvoltarea tulpinilor bacteriene rezistente să fie încetinită. România a avut cea mai mare incidență a TB dintre țările din UE, iar din 2018 a fost introdus un program activ de screening pentru monitorizarea și identificarea cazurilor de TB în rândul populațiilor vulnerabile. Studiul a avut ca scop identificarea tuturor pacienților diagnosticați cu TB la nivelul județului Dolj în 2018 și evaluarea caracteristicilor acestora, precum și estimarea sumelor rambursate de Fondul Național de Asigurări de Sănătate, pe baza datelor raportate de spitalele din Dolj. Tratamentul a fost analizat prin statistici descriptive, pentru cazurile internate pe baza unui diagnostic principal de TB, care au primit îngrijiri continue în anul 2018. În Dolj, în 2018, 6378 persoane au fost infectate cu Mycobacterium tuberculosis. Mai mult de jumătate (3723) dintre acestea erau bărbați (adică 58\%) și $2655(42 \%)$ erau femei. Rezultatele tratamentului administrat pacienților cu TB au fost: $1441(22,6 \%)$ au fost vindecați, $5036(78,9 \%)$ au finalizat tratamentul, $25(0,4 \%)$ au murit, 47 $(0,7 \%)$ au eșuat tratamentul și $163(2,6 \%)$ au întrerupt tratamentul. Numărul persoanelor care au avut un tratament eșuat și al celor care au întrerupt tratamentul reprezintă un rezultat nefavorabil cu privire la administrarea farmacoterapiei antituberculoase și a fost mai mic de 210 pacienți $(3,3 \%)$ în 2018, ceea ce reprezintă un indicator foarte bun în comparație cu obiectivul OMS de a avea $85 \%$ dintre pacienți care finalizează cu succes tratamentul pentru TB.

Keywords: Mycobacterium tuberculosis, isoniazid, rifampicin, pyridoxine, direct costs

\section{Introduction}

Mycobacterium tuberculosis (M.tb.) is one of the most insidious and slow-growing bacilli, which enters human organisms through cough and expelled air droplets derived from sputum and saliva, and initiates tuberculosis (TB), a communicable airborne and challenging disease [12, 33, 35]. Infectious patients, with sputum-smear positive pulmonary disease, are able to transmit M.tb. to other individuals who might present three different outcomes: immediate and 
immunological bacterial removal, primary active TB or latent infection, without clinical manifestations, but which can reactivate after 5 years $[5,22]$.

Although M.tb. commonly enters the respiratory system, there can be other damaged sites (lymph nodes, skeletal sites, pleural and abdominal sites, central nervous system) where the bacteria can determine fewer, but more severe symptoms than in pulmonary $\mathrm{TB}$, therefore commencing extrapulmonary disease forms $[2,5,16,22]$. Cases of extrapulmonary TB are more difficult to diagnose and often present delayed signs such as low-grade constant fever, sterile pyuria, haematuria (genitourinary TB), cervical and subclavicular nodes (lymphadenitis), spinal constitutional modifications (Pott's disease), abnormal behaviour, headaches or convulsions (meningeal TB) [2, 16, 24]. The histopathological structures which define TB and allow M.tb. to persist for decades, under a low metabolic rate, are granulomas observed in both latent and active infection $[2,16,22]$. The disease outcomes depend on the interaction of the host with the bacilli; therefore, granulomas are involved not only in control of infection, but also in pathogenesis [2, 22]. In order to prevent dissemination, macrophages encounter M.tb. and create an immunologic host-protective environment, by recruiting phagocytic cells such as monocytes, lymphocytes, neutrophils and more uninfected macrophages [2]. An inflammatory response is further initiated through cytokine production and chemokine secretion, leading to tissue remodelling $[2,16]$. Calcified granulomas, with fewer inflammatory cells, appear as hallmarks in latent TB, whereas in active TB, the host often presents high granulomatous inflammation, disruption of immunoregulatory mechanism and macrophage necrosis [16, 24].

The granuloma is actually a dynamic lesion, because it involves multiple cell interaction and proliferation, and can easily shift from bacilli containment to bacilli release [2]. In the absence of antituberculotic treatment, the lesions are slowly progressive, destructive, being accompanied by an intense process of perilesional fibrosis $[2,16,24]$. On the other hand, after long-term pharmacotherapy, the caseating granulomas may be replaced by fibrosis, through collagen accumulation and calcification, therefore early diagnosis and clinical research could lead to better antituberculotic treatment outcomes [2, 18].

According to World Health Organisation (WHO), one of every three TB patients, especially from highburden countries such as South Africa, India, China, Russian Federation, is not included in special TB surveillance international health programs [5, 34]. Patients who had TB once have an increased risk of disease relapse, even shortly after completing antiTB treatment $[1,13]$. Furthermore, recent trials have shown that 5 - $8 \%$ of patients fail treatment and also, that patients with high smear grade (3+) at baseline are more likely to interrupt treatment compared to patients with lower smear grades [15, 20]. In fact, it has been shown that even a small number of missed doses and non-adherence increase the risk for poor outcomes and resistant M.tb. strains, which further lead to multi-drug resistant TB (MDR-TB) and to the impossibility of public health systems to truly stop the TB evolution and transmission [5, 20, 26].

Assessing the burden of TB is a topic of permanent interest of public health researchers and health-care decision-makers to measure the cost of illness (COI) and to evaluate the potential costs and benefits of public health interventions. COI analysis may include direct costs (medical costs, non-medical costs), productivity losses, and intangible costs of the TB and can quantify the magnitude of the problem [17].

The aim of this study was to identify all the patients diagnosed with TB in Dolj County, Romania, in 2018 and to evaluate their characteristics, as well as to estimate the amounts reimbursed by the National Health Insurance Fund, based on the data reported by the hospitals from Dolj County.

\section{Materials and Methods}

The study was approved by The Ethic Committee of The University of Medicine and Pharmacy of Craiova, Romania (Nr.5/17.01.2019).

We used anonymized individual patient data reported by hospitals from Dolj County, Romania, at the Health Insurance House of Dolj, following the legal requirements on personal data protection. The patients' dataset extracted from Health Insurance House of Dolj for 2018 included the following demographic and clinical information: patient gender, age, hospital, treatment and outcome (cured, completed, died, failed, interrupted - from WHO definitions [36, 37]), length of stay (hospital days), results of laboratory analysis. Data were collected from the patients' records at the healthcare hospitals from South-west Romania (Craiova, Calafat, Filiași, Dăbuleni, Băilești and Leamna). The treatment could be analysed only for those cases admitted in the hospital with continuous care and diagnosed with TB as principal diagnosis in 2018. We investigated service burden and costs in association with TB.

Data have been extracted and processed in Excel. Data were analysed using the GraphPad Prism 9 software (GraphPad Software, LLC, San Diego, CA, USA). Descriptive statistics were used to summarize patients and their characteristics using percentages for categorical variables and mean \pm standard deviation for continuous variables. We used the T-test (for normal distributed variables) and nonparametric Mann-Whitney U test (for variables without normal distribution). Categorical variables were compared using Chi-square test. It was considered statistically significant at the 5\% level (two-tailed). 


\section{Results and Discussion}

In 2018, 6,378 people have been reported to be infected with M.tb. in Dolj County, Romania. More than a half were males $(3,723$ patients, $58 \%)$ and 2,655 patients $(42 \%)$ were females. The mean age was $39 \pm 30.42$ years. The prevalence of TB in the Dolj County, Romania, was $1.01 \%$ in 2018.

The treatment outcomes of TB patients were: 1,441 (22.6\%) cured, 5,036 (78.9\%) treatment completed, 25 $(0.4 \%)$ died, $47(0.7 \%)$ failed, $163(2.6 \%)$ interrupted. The treatment success is the number of patients cured and treatment completed, but some of the cured patients were also treatment completed in the same year, 2018. The unfavourable treatment outcome is the number of patients with treatment failed and treatment interrupted less than 210 patients $(3.3 \%)$. It is a very good indicator compared with $85 \%$ target of $\mathrm{TB}$ treatment success.

With 25 cases of fatal TB, for a population of 630,911 in the Dolj County, we found a TB death rate of 3.96 (per 100,000 people). Of the 25 patients who died of TB in 2018, two (approximately $8 \%$ ) were females. The mean age was $60.2(\mathrm{SD}=11.12)$. The youngest patient had 38 years old and the oldest was 78 years old.

1,099 cases have been reported to receive treatment in hospitals from Dolj County in 2018, of which 308 patients $(28 \%)$ were females and 791 patients $(72 \%)$ were males. The number of patients with continuous care in hospitals from Dolj County is presented in Figure 1. Patients from Craiova hospital constitute the largest population, 714 cases (52\%), followed by Leamna hospital with 313 patients (23\%).

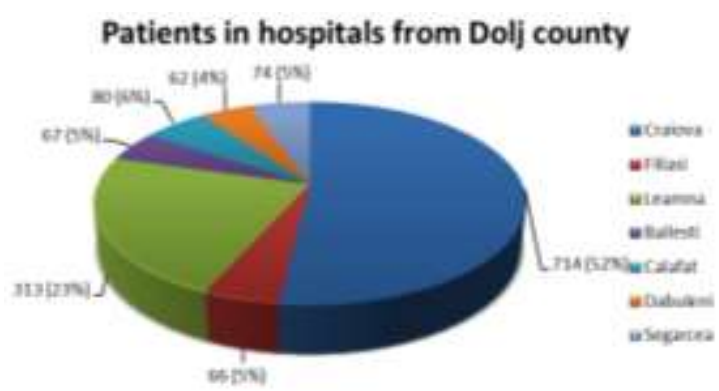

Figure 1.

Distribution of tuberculosis patients with continuous care in hospitals from Dolj County, Romania, in 2018

The use of TB treatment and their dimension were extracted and presented in Table I.

Table I

Number of patients with tuberculosis for each treatment

\begin{tabular}{|c|c|c|c|c|c|c|c|}
\hline & \multicolumn{6}{|c|}{ Number of patients (\%) } \\
\hline & & $\begin{array}{c}\text { Isoniazidum } \\
(\mathbf{n}=\mathbf{1 0 3 2})\end{array}$ & $\begin{array}{l}\text { Rifampicinum } \\
(\mathbf{n}=\mathbf{1 0 3 1})\end{array}$ & $\begin{array}{l}\text { Combination } \\
\text { Rifampicinum + } \\
\text { izoniazidum } \\
(\mathbf{n}=\mathbf{2 0 9})\end{array}$ & $\begin{array}{l}\text { Ethambutolum } \\
\quad(\mathbf{n}=925)\end{array}$ & $\begin{array}{l}\text { Pyrazinamidum } \\
\quad(\mathrm{n}=\mathbf{8 7 8})\end{array}$ & $\begin{array}{l}\text { Streptomycinum } \\
\quad(n=59)\end{array}$ \\
\hline \multirow{2}{*}{ Gender } & Male & $966(94 \%)$ & $733(71 \%)$ & $163(78 \%)$ & $680(74 \%)$ & $644(73 \%)$ & $49(83 \%)$ \\
\hline & Female & $66(6 \%)$ & $298(29 \%)$ & $46(22 \%)$ & $245(26 \%)$ & $234(27 \%)$ & $10(17 \%)$ \\
\hline \multirow{10}{*}{ Age } & $<7$ & $14(1 \%)$ & $14(1 \%)$ & $1(<1 \%)$ & $11(1 \%)$ & $11(1 \%)$ & 0 \\
\hline & $7-12$ & $13(1 \%)$ & $13(1 \%)$ & 0 & $12(1 \%)$ & $12(1 \%)$ & 0 \\
\hline & $13-24$ & $90(9 \%)$ & $90(9 \%)$ & $16(7 \%)$ & $77(8 \%)$ & $75(9 \%)$ & $1(1.7 \%)$ \\
\hline & $25-34$ & $146(14 \%)$ & $144(14 \%)$ & $24(11 \%)$ & $116(13 \%)$ & $114(13 \%)$ & $2(3.4 \%)$ \\
\hline & $35-44$ & $171(17 \%)$ & $176(17 \%)$ & $42(20 \%)$ & $158(17 \%)$ & $152(17 \%)$ & $9(15.3 \%)$ \\
\hline & $45-54$ & $242(23 \%)$ & $247(24 \%)$ & $62(29 \%)$ & $237(26 \%)$ & $218(25 \%)$ & $19(32 \%)$ \\
\hline & $55-64$ & $207(20 \%)$ & $201(19 \%)$ & $40(19 \%)$ & $186(20 \%)$ & $171(19 \%)$ & $14(24 \%)$ \\
\hline & $65-74$ & $91(9 \%)$ & $89(9 \%)$ & $17(8 \%)$ & $76(8 \%)$ & $76(9 \%)$ & $10(17 \%)$ \\
\hline & $75-84$ & $52(5 \%)$ & $51(5 \%)$ & $7(3 \%)$ & $47(5 \%)$ & $45(5 \%)$ & $4(7 \%)$ \\
\hline & $>84$ & $6(1 \%)$ & $6(1 \%)$ & 0 & $5(1 \%)$ & $4(0.5 \%)$ & 0 \\
\hline
\end{tabular}

The highest percentage of patients from Dolj County received isoniazid $(\mathrm{H})$ (1,032 patients from a total of 1,099 cases) and rifampicin (R) (1,031 patients from a total of 1,099 cases), the most effective bactericidal drugs. Streptomycin (S) was the least administered substance in 2018, especially in children and elderly. Most of TB cases appear in young adults, especially men $(94 \%)$ between 45 and 54 years old. On the contrary, children (below 7 and 7 - 12 years old) and elderly (over 84 years old) represent a low proportion of the total cases reported in Dolj County in 2018. The number of new cases in 2018 could not be determined, but the number of patients with multi- drug resistant TB (MDR-TB) was calculated according to the reported treatment. A number of 266 patients had MDR-TB, of which 218 were men (82\%) and 48 were women $(18 \%)$. The mean age was $49.32 \pm 13.67$ years, as reported in Figure 3.

The proportion of MDR-TB patients' treatment was: five patients treated with amikacin, 39 patients treated with cycloserine, four patients treated with levofloxacin, 176 patients treated with ofloxacin, 42 patients treated with protionamide, as reported in Table II. 


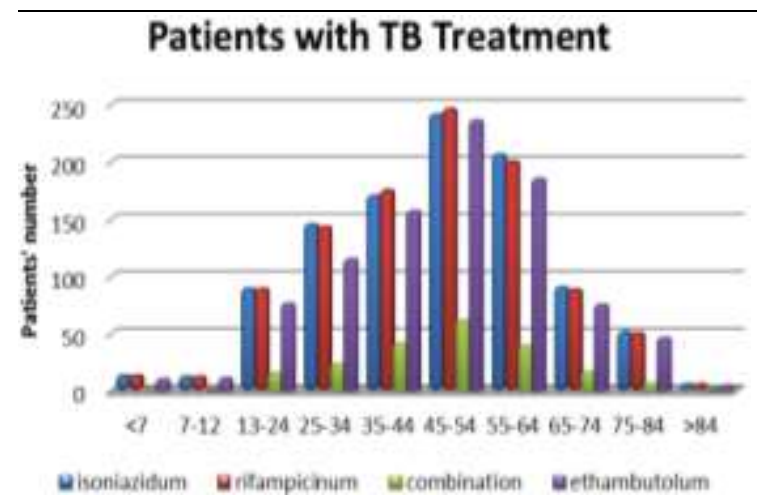

Figure 2.

Distribution of patients for different antituberculosis treatment in Dolj County, Romania, in 2018

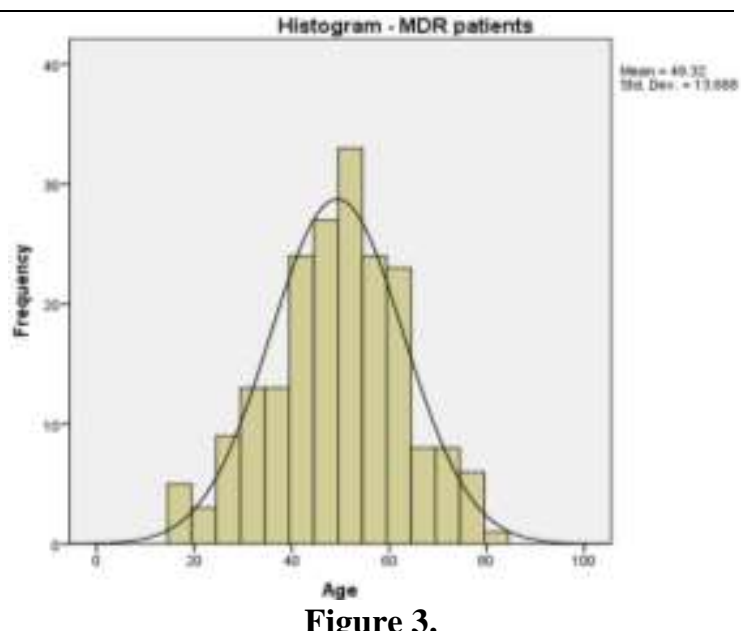

Figure 3.

The normal distribution of age for the MDR-TB patients

Table II

Number of patients with MDR-TB for each treatment

\begin{tabular}{|c|c|c|c|c|c|c|}
\hline & \multicolumn{5}{|c|}{ Number of patients (\%) } \\
\hline & & $\begin{array}{c}\text { Amikacinum } \\
(\mathbf{n}=5)\end{array}$ & $\begin{array}{c}\text { Cycloserinum } \\
(\mathbf{n}=39)\end{array}$ & $\begin{array}{c}\text { Levofloxacinum } \\
(\mathrm{n}=4)\end{array}$ & $\begin{array}{c}\text { Ofloxacinum } \\
(\mathbf{n}=176)\end{array}$ & $\begin{array}{l}\text { Protionamidum } \\
\quad(n=42)\end{array}$ \\
\hline \multirow{2}{*}{ Gender } & Male & $5(100 \%)$ & $32(82 \%)$ & $2(50 \%)$ & $147(84 \%)$ & $32(76 \%)$ \\
\hline & Female & 0 & $7(18 \%)$ & $2(50 \%)$ & $29(16 \%)$ & $10(24 \%)$ \\
\hline \multirow{10}{*}{ Age } & $<7$ & 0 & 0 & 0 & 0 & 0 \\
\hline & $7-12$ & 0 & 0 & 0 & 0 & 0 \\
\hline & $13-24$ & 0 & $2(5 \%)$ & 0 & $5(3 \%)$ & $2(5 \%)$ \\
\hline & $25-34$ & $2(40 \%)$ & $2(5 \%)$ & $3(75 \%)$ & $20(11 \%)$ & $4(10 \%)$ \\
\hline & $35-44$ & 0 & $8(21 \%)$ & 0 & $34(19 \%)$ & $6(14 \%)$ \\
\hline & $45-54$ & $3(40 \%)$ & $11(28 \%)$ & 0 & $57(32 \%)$ & $11(26 \%)$ \\
\hline & $55-64$ & 0 & $12(31 \%)$ & $1(25 \%)$ & $43(24 \%)$ & $12(29 \%)$ \\
\hline & $65-74$ & 0 & $3(8 \%)$ & 0 & $13(7 \%)$ & $4(10 \%)$ \\
\hline & $75-84$ & 0 & $1(3 \%)$ & 0 & $4(2 \%)$ & $3(7 \%)$ \\
\hline & $>84$ & 0 & 0 & $2(50 \%)$ & 0 & 0 \\
\hline
\end{tabular}

The number of complex drug resistance patients was high, $266(24.2 \%)$, ofloxacin being the most used drug for treatment of MDR-TB patients, as shown in Figure 4.

The highest percentage $(24 \%)$ of patients receiving pyridoxine, as a supplement during $\mathrm{H}$ therapy, was between 45 and 54 years old, followed by those between 55 and 64 years old (21\%) (Table III).

We compared the group of TB patients with MDR-TB treatment (who received second-line antituberculotic agents) with the group of patients without MDR-TB treatment (who received first-line antituberculotic agents). The results are shown in Table IV. No significantly difference was found for age between the two groups. Instead, the gender was different between the two groups, with more men in the MDR-TB treatment group.

After we investigated the economic impact of TB and the service utilization pattern of patients with TB in the Dolj county, we obtained a value of direct costs of RON 45,390,457 (approximately \$10,531,429, with $\$ 1=$ RON 4.31). The direct costs associated with TB were drug administration ( $\mathrm{RON} 327,170.5=\$ 75,910)$, hospitalization days (number $=100,961$, value $=$ RON $44,929,664=\$ 10,424,516)$, the medical consultation (number $=8,787$, value $=$ RON 97,327.35 $=\$ 22,582$ ) and laboratory tests (number $=1,707$, value $=$ RON $36,295.64=\$ 8,421)$.

\section{Patients with MDR-TB Treatment}

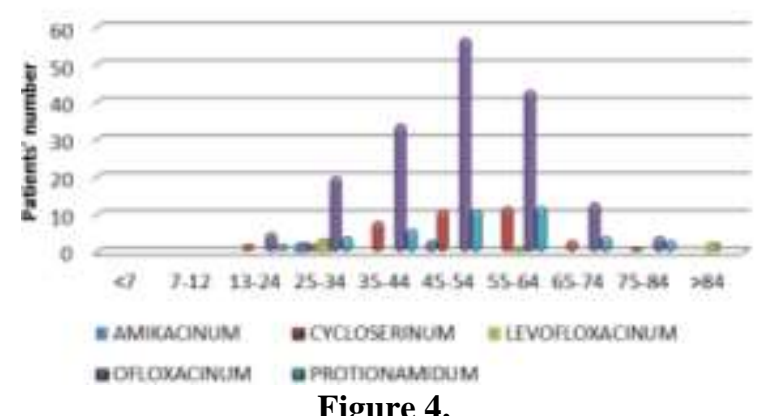

Distribution of patients for different MDR-TB treatment in Dolj County, Romania, in 2018 
Number of patients with pyridoxine supplementation during therapy

\begin{tabular}{|l|l|c|c|}
\hline \multicolumn{2}{|c|}{} & $\begin{array}{c}\text { Number of patients receiving pyridoxinum } \\
(\mathrm{n}=921)(\%)\end{array}$ & Mean of the number of drugs given/patient \\
\hline \multirow{3}{*}{ Gender } & Male & $675(73 \%)$ & 19 \\
\cline { 2 - 4 } & Female & $246(27 \%)$ & 16 \\
\hline \multirow{5}{*}{ Age } & $<7$ & $8(0.9 \%)$ & 6 \\
\cline { 2 - 4 } & $7-12$ & $13(1.4 \%)$ & 9 \\
\cline { 2 - 4 } & $13-24$ & $78(8 \%)$ & 10 \\
\cline { 2 - 4 } & $25-34$ & $121(13 \%)$ & 13 \\
\cline { 2 - 4 } & $35-44$ & $159(17 \%)$ & 22 \\
\cline { 2 - 4 } & $45-54$ & $224(24 \%)$ & 21 \\
\cline { 2 - 4 } & $55-64$ & $193(21 \%)$ & 19 \\
\cline { 2 - 4 } & $65-74$ & $78(8 \%)$ & 22 \\
\cline { 2 - 4 } & $75-84$ & $43(5 \%)$ & 12 \\
\cline { 2 - 4 } & $>84$ & $4(0.4 \%)$ & 10 \\
\hline
\end{tabular}

Table IV

Characteristics of MDR-TB patients vs. non-MDR-TB patients

\begin{tabular}{|l|l|c|c|c|}
\hline & & MDR-TB patients & Non-MDR-TB patients & p-value \\
\cline { 2 - 5 } \multirow{2}{*}{ Gender } & Male & $162(13 \%)$ & $790(61 \%)$ & \multirow{2}{*}{0.0026} \\
& Female & $35(3 \%)$ & $308(24 \%)$ & \multirow{2}{*}{0.0658} \\
\hline \multirow{2}{*}{ Age } & Mean (SD) & $49.32(13.67)$ & $46.8(17.2)$ & $48(24.75)$ \\
& Median (IQR) & $50(18)$ & \\
\hline
\end{tabular}

$\mathrm{SD}=$ Standard Deviation; IQR = Interquartile Range

According to WHO, in 2018, more than 10 million people (5.8 million men, 3.2 million women and over 1.0 million children under 15 years old) proved nonspecific and common TB symptoms such as chronic cough, night sweats, fever, weight loss, a general feeling of discomfort and 1.5 million died [5, 35]. Despite the fact that Europe counts less than $3 \%$ of TB cases worldwide, Romania presents the highest incidence [5, 12, 35]. Romania, with a 20 million population, notified in 2018 approximately 13.000 new TB cases (68\%), with 3200 cases among HIVpositive patients $(1.6 \%)$ and $7100(3.6 \%)$ MDR-TB cases [35].

In the past years, our country has intensified efforts in order to increase notification of new cases, often associated with behavioural and demographic factors, but also to ensure a correct diagnosis and the most effective treatment, through national surveillance programs [12, 33]. The concerning number of deaths among HIV-negative people in Romania, in 2018 (8600), with a rate of $4.4 \%$, claimed the importance to determine a report regarding the number of deaths, number of confirmed cases and number of relapse cases in order to reduce the incidence of active TB and MDR-TB [35].

Although, some studies reported no significant differences between men and women regarding any anti-TB drug resistance [11], MDR-TB prevalence has been noted with a higher rate in male patients $[6$, 10]. Our report noted three times more men with MDRTB treatment in comparison with ones receiving firstline antituberculotic agents. Unfortunately, we could not differentiate from our database if the MDR-cases were relapses due to low first-line pharmacotherapy adherence or new cases.

Htun et al. proved that female sex predisposes to longer treatment delay, which further leads to difficulty in controlling MDR-TB, but the retrospective study was conducted in a Regional TB Centre from Myanmar [14]. On the other hand, The European Surveillance System (TESSy) used a multivariable regression model for ten years (2002-2011) in a cohort study including 28 countries and underlined a higher proportion of men who died or failed completing antituberculotic treatment, including second-line agents, therefore a lower treatment success rate for male sex [19]. Even more, Chaves Torres et al. emphasized that female sex speeds better anti-TB treatment outcomes [6]. Our study accentuates actual difficulties in controlling TB epidemic, sustained especially by the growing number of MDR-TB cases reported in the past years [19, 35]. TESSy reported Romania as one of the countries that showed an increasing treatment success rate throughout ten years in patients diagnosed with MDR-TB, even though Romania was also one of the top three countries that had surpassed more than $10 \%$ of unsatisfactory anti-TB treatment outcomes [19]. Glausser et al. ranked migrants born-cases in Romania as the $3^{\text {rd }}$ place regarding antituberculotic drug resistance, after Somalia and Eritrea, in a study conducted in Germany between 2008 and 2017, based on surveillance data [11]. Proportions of age groups and sex between MDRTB-patients and TB-patients did not change in our study, consistent with TESSy trend analysis [19]. For countries within the European Union (EU) and European Economic Area (EEA), WHO and European 
FARMACIA, 2021, Vol. 69, 1

Centre for Disease Prevention and Control (ECDC) recommended a treatment success rate of $85 \%$ at 12 months for all new culture positive pulmonary TB cases and a treatment success rate of $90 \%$ for all new smear positive pulmonary TB cases [9]. In our report, we couldn't differentiate new culture positive pulmonary TB cases or new smear positive PTB cases, but we found a successful treatment rate for Dolj County which indicates that Romania could be able to meet WHO/ECDC targets for TB treatment success.

The number of TB patients showed age-specific differences with a higher proportion reported for 35 65 years. Our data confirm that most of TB cases appear in young adults, especially men (94\%) of 45 54 years old, which is in line with other studies showing a higher susceptibility of men due to an X chromosome gene [40], consistent with WHO notification regarding men predisposition to develop TB with a higher rate than women [5, 35, 37]. Although TB in children remains rare in Dolj County, when present it can lead to severe disease, with common dissemination in meninges, bone marrow and urinary tract $[8,27]$. Therefore, TB among children continues to demand special attention not only because of their treatment particularity, but also as an indicator of current transmission among the population. The low proportion of active TB cases in children (below 7 and $7-12$ years old) and elderly (> 84 years old) reported in Dolj County, in 2018, underlined a promising result of all the efforts Romania has made in the last years in order to ease the TB burden.

This calls attention to the importance of keeping continued vigilance against TB for all age groups and the consideration for differential diagnosis also based on histopathological examinations. The reduction of TB prevalence can be realized by avoiding riskfactors such as: contact with other TB cases or foreignborn persons from endemic areas, smoking, heavy alcohol consumption and administration of immunocompromising drugs [5, 33]. Furthermore, taking actions regarding life quality and poor nutrition in patients can decrease not only the local incidence of TB in Romania, but also the global number of deaths, estimated by WHO at almost 1.2 million among HIVnegative people in 2018 [5, 10, 31, 35]. TB mortality rate per 100,000 had a decreasing slope. In 2017, TB death rate for Romania was 4.7 cases per 100,000 people, which dropped from 10 cases per 100,000 people in 2003 and 7.7 in 2007 [31, 39]. TB death rate per 100,000 people in Romania in 2018 was reported at 4.4 and we found a very significant outcome (3.96) to this indicator for Dolj County. The TB mortality rate (ICD A15-19) of 3.96 cases per 100,000 is an indicator met only in Lithuania and Romania by all EU/EEA Member States being more than the target of $2.7 \%$ [37].

Early adopted anti-TB treatment can control the progression of the disease and can prevent drug resistance [29, 34]. According to WHO, a cured patient is one who was initially sputum smear-positive, but after treatment or before completion of treatment, is sputum smear negative on at least two previous occasions, usually at the end of the second and fifth month $[15,35,37]$. The standard recommended antiTB treatment represents a six months regimen containing a two months intensive phase with $\mathrm{H}, \mathrm{R}$, pyrazineamide (Z), ethambutol (E), followed by a continuous phase of four months $[1,5,9,15,40]$. Our data supports WHO guidelines recommendations, the highest percentage of patients from Dolj County receiving $\mathrm{H}$ and $\mathrm{R}$ which are also the most effective bactericidal drugs in preventing MDR-TB strains [3, 5, 15]. One of the reasons of high recommendation of $\mathrm{H}$ and $\mathrm{R}$ may highlight the efforts specialists from Dolj County have made in the last years in order to strengthen latent TB treatment surveillance. We underline that the most used treatment for latent TB represents a daily combination of these two drugs, orally administered, for three months [2, 28]. Treating latent TB is mandatory in order to eliminate the global TB burden [29].

On the other hand, streptomycin (S) can be administered as an alternative to $\mathrm{E}$, but is not recommended in uncomplicated cases [5]. In 2018, S was the least administered substance in Dolj County, especially in children and elderly, because it requires parenteral injection and provides a risk of renal impairment, irreversible vestibular-cochlear nerve damage, deafness and neuromuscular blockade $[4,5]$. WHO recommends using $\mathrm{S}$ and other aminoglycosides only in critical situations, without any alternative drugs $[4,15,20]$. The large number of patients with complex drug resistance, which contributes to a higher incidence of $\mathrm{TB}$ in population risk groups, as well as high proportions of infectious PTB demonstrate that TB is still a disease with significant public health relevance in Romania. The costs of treating MDR-TB and XDRTB actually exceed the total budget for TB control in high-burden countries worldwide, so combating and preventing resistant strains has not only human consequences, but also economic ones [34, 40]. The most prescribed second-line anti-TB drug in 2018 was ofloxacin, a cost-effective fluoroquinolone, with increased adherence due to oral administration and low risk of adverse reactions [5, 40]. Though, common side effects such as increased hepatic enzymes, gastrointestinal disorders or even cardiovascular, by prolonging QT interval and by generating arrhythmias, could appear [3,5].

Another analysed data regards the co-administration of pyridoxine (vitamin B6) and $\mathrm{H}$, with the highest percentage in patients aged $45-64$, included also in the highest proportion of TB cases. There are several recent studies that also noted more adverse reactions in patients over 35 years old [13, 21]. Risk groups such as malnourished, immunocompromised, diabetic patients, alcohol consumers and pregnant women 
FARMACIA, 2021, Vol. 69, 1

are recommended to orally administrate $10-50 \mathrm{mg}$ pyridoxine in order to reduce $\mathrm{H}$-induced neuropathy or other neurological disorders [4, 5, 8, 22]. Furthermore, the role of micronutrients and vitamins in TB prophylaxis and treatment is being widely discussed and it seems that vitamin $\mathrm{C}$ leads to a dormancy state of M.tb, stimulating the bacteriostatic effect of antituberculotic drugs, while vitamin D has an immunomodulatory function and stimulates host immunity to rapidly kill the bacteria [13, 22, 29].

The strengths of the study include the populationwide approach with TB from Dolj for 1 year, with no missing patients to ensure complete reimbursements.

One of the limitations of this study was the missing of some information that were not included in the database: other disease conditions (like HIV-infection or other viral co-infection or medical conditions), other treatments (with drugs that can interact with TB drugs $[13,22])$ or other associated factors that could be important in disease progression and mortality among TB cases, as TB re-treatments or lack of therapy compliance $[7,23]$. New strategies could be implemented for assessing [23, 32] and guarantee for a complete adherence to TB therapy.

Using data from the Health Insurance House of Dolj, it was important to estimate the TB burden among children or adolescents in the Dolj County, and for every segment of age. The average expenditure per notified TB patient (US\$ per patient) reported to WHO for Romania in 2018 was of approximately US\$ 450. We found a burden of US\$ 1651 per patient with TB in Dolj County [30, 36, 38], which is almost four times the national reported data. TB was associated with increased service use and costs in Dolj County. Future local plans to address the goal of TB elimination and minimization of financial burden $[25,36]$ will need to take this into account.

From all 12,205 TB case notifications in 2018 in Romania in WHO's global TB database [36, 38], $6,378(52 \%)$ are only in Dolj County. This study indicates that the prevalence of tuberculosis in Dolj County is still high, but with more than $85 \%$ of treatment success.

\section{Conclusions}

Even though TB is the most prevalent contagious disease cause of death, determining more than 3 million deaths each year, the improvement of $\mathrm{TB}$ control strategies and progresses made in predicting new cases may lower future epidemics. The analysis of notified cases or treatment outcomes needs further exploration in order to predict prevalence rates in specific geographic areas, but could be a solution to obtain positive results. According to WHO End TB Strategy, these results should be translated through a percentage of treatment success rates higher than $90 \%$.
Conflict of interest

The authors declare no conflict of interest.

\section{References}

1. Ambreen A, Jamil M, Aqeel ur Rahman M, Mustafa T, Viable Mycobacterium tuberculosis in sputum after pulmonary tuberculosis cure. BMC Infect Dis., 2019; 19: 923: 1-8.

2. Balcells ME, Yokobori N, Hong B, Corbett J, Cervantes $\mathrm{J}$, The lung microbiome, vitamin $\mathrm{D}$, and the tuberculous granuloma: a balance triangle. Microb Pathog., 2019; 131: 158-163.

3. Bloom BR, Atun R, Cohen T, Dye C, Fraser H, Gomez GB, Knight G, Murray M, Nardell E, Rubin E, Salomon J, Vassall A, Volchenkov G, White R, Wilson D, Yadav P, Chapter 11 Tuberculosis. In: KK Holmes, S Bertozzi, BR Bloom, P Jha (ed). Major Infectious Diseases, Disease Control Priorities, Vol. 6, Washington DC, 2017; 233-313.

4. Bullock S, Manias E, The modulation of cellular growth and proliferation, Antituberculotic and Antileprotic Agents. In: Bullock S, Manias E (ed). Fundamentals of Pharmacology, Pearson Australia, 2014; 948-959.

5. Capstick T, Whitaker P, Chapter 41 Tuberculosis. In: Whittlesea C, Hodson K (ed). Clinical Pharmacy and Therapeutics, Elsevier, London, 2018; 673-687.

6. Chaves Torres NM, Quijano Rodriguez JJ, Porras Andrade PS, Arriaga MB, Netto EM, Factors predictive of the success of tuberculosis treatment: A systematic review with meta-analysis. PLOS ONE, 2019; 14(12): e0226507: 1-24

7. Croitoru O, Spiridon AM, Belu I, Turcu-Stiolica A, Neamtu J, Development and validation of an HPLC method for simultaneous quantification of clopidogrel bisulfate, its carboxylic acid metabolite and atorvastatin in human plasma: application to a pharmacokinetic study. J Anal Methods Chem., 2015; 2015: 1-12.

8. Deck DH, Winston LG, Chapter 47 Antimycobacterial drugs. In: Katzung GB, Masters BS, Trevor JA (ed). Basic\&Clinical Pharmacology, McGrawHill Medical, 2012; 839-848.

9. ECDC, Special Report: Progressing towards TB elimination, A follow-up to the Framework Action Plan to Fight Tuberculosis in the EU (2010). Stockholm: ECDC, 2010, 2010: 1-29.

10. Fildan AP, Arghir IA, Popescu GG, Matei C, Nemes RM, Tofolean D, Dantes E, Pop CS, Cambrea SC, The prevalence and spectrum of Mycobacterium tuberculosis chemoresistance among TB patients. Farmacia, 2020; 68(1): 129-134.

11. Glasauer S, Altmann D, Hauer B, Brodhun B, Haas W, Perumal N, First-line tuberculosis drug resistance patterns and associated risk factors in Germany, 2008-2017. PLOS ONE, 2019, 14(6): e217597: 1-18.

12. Golli AL, Nitu MF, Turcu F, Popescu M, CiobanuMitrache L, Olteanu M, Tuberculosis remains a public health problem in Romania. Int J Tuberc Lung Dis., 2019; 23(2): 226-231.

13. Grecu VI, Olteanu M, Maceseanu AV, Nitu FM, Calarasu C, Turcu AA, Study of the Trend of Respiratory and Extra-Respiratory Tuberculosis in a Southern Region of Romania between 2011-2018. J Qual Healthcare Econom., 2019, 2(4): 000128: 1-6. 
FARMACIA, 2021, Vol. 69, 1

14. Htun YM, Khaing TMM, Aung NM, Yin Y, Myint Z, Aung ST, Soonthomworasiri N, Silachamroon U, Kasetjaroen Y, Kaewkungwal J, Delay in treatment initiation and treatment outcomes among adult patients with multidrug-resistant tuberculosis at Yangon Regional Tuberculosis Centre, Myanmar: A retrospective study. PLoS ONE, 2018; 13(12): e0209932: 1-5.

15. Imperial MZ, Nahid P, Phillips PPJ, Davies GR, Fielding K, Hanna D, Hermann D, Wallis RS, Johnson JL, Lienhardt C, Savic RM, A patient-level pooled analysis of treatment shortening regimens for drugsusceptible pulmonary tuberculosis. Nat Med., 2018; 24(11): 1708-1715.

16. Jilani TN, Avula A, Gondal Zafar A, Siddiqui AH, Active Tuberculosis. $1^{\text {st }}$ Edition, StatPearls Publishing, Treasure Islands, FL, 2020; 1-52.

17. Jo C, Cost-of-illness studies: concepts, scopes, and methods. Clin Mol Hepatol., 2014; 20(4): 327-337.

18. Kandasamy S, Govindarajalou R, Chakkalakkoombil SV, Penumadu P, Isolated hepatobiliary tuberculosis: a diagnostic challenge. BMJ Case Rep., 2018; 2018: bcr-2017-223912: 1-4.

19. Karo B, Hauer B, Hollo V, van der Werf MJ, Fiebig L, Haas W, Tuberculosis treatment outcome in the European Union and European Economic Area: an analysis of surveillance data from 2002-2011. Euro Surveill., 2015; 20(49): 1-10.

20. Lenaerts A, Barry III CE, Dartois V, Heterogeneity in tuberculosis pathology, microenviroments and therapeutic responses. Immunol Rev., 2015; 264(1): 288-307.

21. Meca AD, Bogdan M, Camen A, Boldeanu MV, Postolache P, Mititelu-Tartau L, Tuberculosis: between the old and the new. Rev Med Chir Iași, 2019; 123(4): 573-582.

22. Namdar R, Lauzardo M, Peloquin CA, Chapter 112. Tuberculosis. In: DiPiro JT, Talbert RL, Yee GC, Matzke GR, Wells BG, Posey LM (eds). Pharmacotherapy: A pathophysiologic Approach 10e, Mc Graw Hill Education, 2017; 4941-4988.

23. Nedelcu RE, Socaci A, Risk factors associated with MDR-TB deaths in Romania - 6 years retrospective study. Eur Resp J., 2018; 52(Suppl.62): PA3677.

24. Nitu FM, Olteanu M, Streba CT, Jimborean G, Postolache P, Man MA, Trofor AC, Nemes RM, Dragonu M, Olteanu M, Tuberculosis and its particularities in Romania and worldwide. Rom $J$ Morphol Embryol., 2017; 58(2): 385-392.

25. Pednekar P, Agh T, Melmenas M, Raval A, Bennett B, Borah B, Hutchins D, Manias E, Williams A, Hiligsmann M, Turcu-Stiolica A, Zeber J, Abrahamyan L, Bunz T, Peterson A, Methods for measuring multiple medication adherence: a systematic review - report of the ISPOR medication adherence and persistence special interest group. Value Health, 2019; 22(2): 139-156.

26. Popescu GG, Arghir OC, Fildan AP, Spanu V, Cambrea SC, Rafila A, Buicu FC, Antibiotic resistance of Mycobacterium tuberculosis; mechanism and specific therapeutic response. Farmacia, 2020; 68(2): 197-205.
27. Rang HP, Ritter JM, Flower RJ, Henderson G, Drugs used for the treatment of infections and cancer, Basic principles of antimicrobial chemotherapy, Antibacterial drugs. In: Ritter J, Flower R, Henderson G, Rang H (ed). Rang and Dale's Pharmacology, Elsevier, London, 2016; 615-641.

28. Schein YL, Madebo T, Andersen HE, Arnesen TM, Dyrhol-Riise AM, Tveiten H, White RA, Askeland Winje B, Treatment completion for latent tuberculosis infection in Norway: a prospective cohort study. BMC Infect Dis., 2018; 18: 587: 1-10.

29. Shastri MD, Shukla SD, Chong WC, Dua K, Peterson GM, Patel RP, Hansbro PM, Eri R, O'Toole RF, Role of Oxidative Stress in the Pathology and Management of Human Tuberculosis. Oxid Cell Med Longev., 2018; 2018: 7695364: 1-10.

30. Subtirelu MS, Meca AD, Pisoschi CG, Bogdan M, Nitu FM, Matei M, Turcu-Stiolica A, PIN92 The economic burden assessment of tuberculosis in Dolj County, Romania: a retrospective analysis. Value Health, 2020; 23(Suppl.1): S184.

31. Tanue EA, Nsagha DS, Njamen TN, Assob NJC, Tuberculosis treatment outcome and its associated factors among people living with HIV and AIDS in Fako Division of Cameroon. PLoS ONE, 2019; 14(7): e218800: 1-14.

32. Turcu-Stiolica A, Taerel AE, Turcu-Stiolica RA, Identifying and measuring compliance and adherence in antidepressants taking. Procedia Econ Financ., 2014; 15: 836-839.

33. Wang J, Wang C, Zhang W, Data Analysis and Forecasting of Tuberculosis Prevalence Rates for Smart Healthcare Based on a Novel Combination Model. Appl Sci., 2018; 8: 1693: 1-24.

34. WHO Guidelines for treatment of drug-susceptible tuberculosis and patient care 2017 update. Geneva World Health Organization, 2017; 2017: 1-56.

35. WHO Global Tuberculosis Report. Geneva World Health Organization, 2019; 2019: 1-261.

36. WHO Library Cataloguing in Publication Data. World Health Organization Definitions and reporting framework for tuberculosis - 2013 revision (updated December 2014). Geneva World Health Organization, 2014; 2014: 1-40.

37. WHO Regional Office for Europe, European Centre for Disease Prevention and Control. Tuberculosis surveillance and monitoring in Europe 2018-2016 data. World Health Organization, 2018; 2018: 181-182.

38. WHO Library Cataloguing in Publication Data. Romania Tuberculosis Profile 2018. WHO Extranet, 2018; 2018: 1

39. World Data Atlas. Romania - Tuberculosis death rate. Health Risk-factors, 2017; 2017: 1.

40. Worku S, Derbie A, Mekonnen D, Biadglegne F, Treatment outcomes of tuberculosis patients under directly observed treatment short-course at Debre Tabor General Hospital, northwest Ethiopia: nine-years retrospective study. Infect Dis Poverty, 2018; 7: 16: $1-7$. 